\title{
Late Caddo Ceramics from 41HE337 in Henderson County, Texas
}

Timothy K. Perttula

Heritage Research Center, Stephen F. Austin State University

Follow this and additional works at: https://scholarworks.sfasu.edu/ita

Part of the American Material Culture Commons, Archaeological Anthropology Commons, Environmental Studies Commons, Other American Studies Commons, Other Arts and Humanities Commons, Other History of Art, Architecture, and Archaeology Commons, and the United States History Commons

Tell us how this article helped you.

This Article is brought to you for free and open access by the Center for Regional Heritage Research at SFA ScholarWorks. It has been accepted for inclusion in Index of Texas Archaeology: Open Access Gray Literature from the Lone Star State by an authorized editor of SFA ScholarWorks. For more information, please contact cdsscholarworks@sfasu.edu. 


\section{Late Caddo Ceramics from $41 \mathrm{HE} 337$ in Henderson County, Texas}

Creative Commons License

(c) (i) (8)

This work is licensed under a Creative Commons Attribution-NonCommercial 4.0 International License 


\title{
Late Caddo Ceramics from $41 \mathrm{HE} 337$ in Henderson County, Texas
}

\author{
Timothy K. Perttula
}

Site 41 HE337 is a Late Caddo settlement located on the north side of Caddo Creek, an eastward-flowing tributary to the Neches River, and just west of the city of Poynor, in Henderson County, Texas. Bill Young, an avocational archaeologist living in Corsicana, Texas, has a substantial collection of Caddo ceramic vessel sherds from the site. ${ }^{1}$ He gave his permission to study and document these materials as part of a broader study I am engaged in of post-A.D. 1300 Caddo ceramic traditions in the upper Neches River basin of East Texas (Perttula 2008).

\section{THE SHERD COLLECTION}

Young's collection consists of 485 sherds, including 24 rims, 24 bases, and 437 body sherds (Table 1).
Proportionally, almost $70 \%$ of the sherds are plain wares, but this undoubtedly includes some plain body sherds and bases from the undecorated portions of the decorated utility wares and fine wares.

To reduce the ambiguity of sherd proportions because of the mix of plain vessel sherds and plain portions of decorated vessel sherds that may be present in the plain wares, a better comparison of the proportions of the different ceramic wares in the Caddo assemblage is the relative frequency of rim sherds (see Table 1). In this case, $29 \%$ of the rims are from plain vessels, another $37.5 \%$ are from utility wares (jars or bowls decorated with wet-paste designs, i.e., vessels decorated before firing), and the remaining $33.3 \%$ are from engraved or lip notched fine wares. On this basis, the proportion of the three wares at $41 \mathrm{HE} 337$ is quite comparable.

Table 1. Ceramic vessel sherds from $41 \mathrm{HE} 337$.

\begin{tabular}{lcccc}
\hline Category & Rim & Body & Base & N \\
\hline Plain ware & 7 & 305 & 24 & 336 \\
\hline Decorated Utility ware & & & & \\
Incised & 3 & 25 & - & 28 \\
Punctated & 2 & 26 & - & 28 \\
Incised-punctated & 4 & 5 & - & 9 \\
Pinched & - & 1 & - & 1 \\
Brushed & - & 52 & - & 52 \\
Brushed-punctated & - & 1 & - & 1 \\
Appliqued & - & 2 & - & 2 \\
Fine ware & & & & \\
Engraved & & & & \\
Lip notched & 7 & 18 & - & 25 \\
Red-slipped & - & - & - & 1 \\
\hline
\end{tabular}




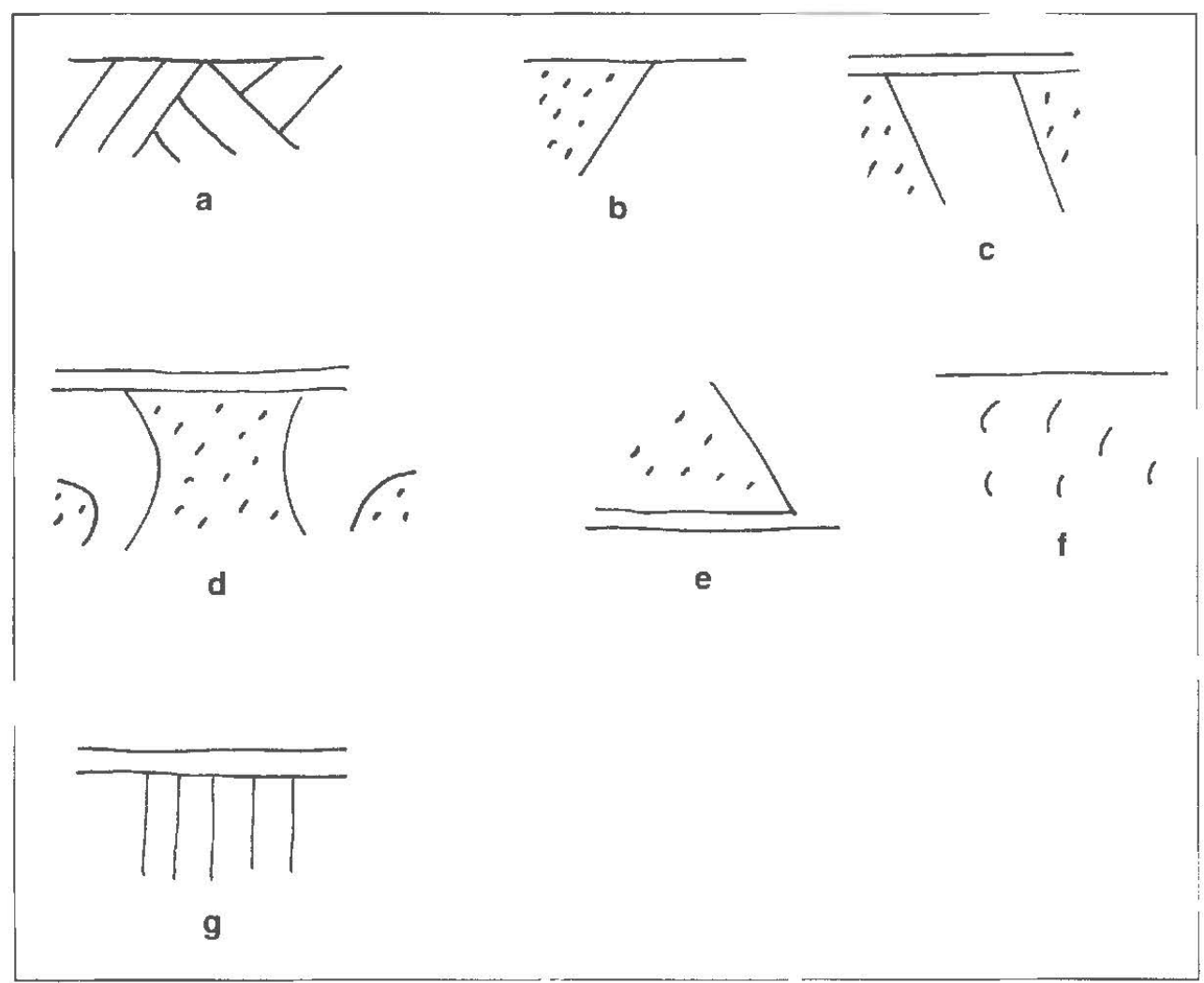

Figure 1. Selected utility wares: a, diagonal opposed Maydelle Incised rim; b, e, incised triangles filled with punctations; $c$, diagonal incised panels filled with tool punctations; $d$, curvilinear incised zones filled with tool punctations; f, straight incised line framing fingernail punctated-filled area: $\mathrm{g}$, vertical incised panel.

\section{Plain wares}

As the rim sherd proportions discussed above indicate, plain vessels comprise a significant proportion of the ceramic vessel sherds from 41HE337, including almost $30 \%$ of the rims. These plain wares appear to be from simple bowls-either smoothed and/or burnished on one or both vessel surfacesthat would have been used by the Caddo for holding and serving foods, most likely for individual use rather than communal use.

\section{Decorated Utility wares}

Overall, brushing is the most common form of decoration in the 41 HE337 utility wares, comprising $43 \%$ of the utility wares (see Table 1). However, none of the brushed sherds are rims, strongly suggesting that brushed decorations in this assemblage are confined to the body of jars; the rims of those jars are most likely decorated with non-brushed elements, among them incised, incised-punctated, and punctated elements (see Table 1), as well as occasionally also being brushed. Brushing on vessel bodies tend to be vertically-oriented or with parallel brushing marks $(90 \%)$ if the orientation is uncertain, but overlapping $(2 \%)$, and opposed $(8 \%)$ brushed body surfaces are also noted in the $41 \mathrm{HE} 337$ assemblage.

One sherd has parallel brushing on it, along with at least one row of tool punctations that have been pushed through the brushing. This kind of brushedpunctated decoration is relatively common in postA.D. 1350 Caddo ceramic assemblages in the Neches and middle Sabine river basins of East Texas.

Sherds with incised decorations $(n=28)$ comprise $23 \%$ of the utility wares. One Maydelle Incised rim has diagonal opposed lines (Figure 1a), a second Maydelle Incised rim has diagonal incised lines, while another rim has a vertical incised panel (Figure $1 \mathrm{~g}$ ). Body sherds have sets of parallel incised lines $(n=8)$, opposed incised lincs $(n=4)$, crosshatched incised lines $(n=3)$, and a single straight incised line $(\mathrm{n}=10)$.

One incised-punctated body sherd is from a jar with diagonal incised lines on the rim and tool punctates on the vessel body. Two others have a single straight 
incised line framing a zone of fingernail punctates (see Figure lf), and a third with a single straight incised line frames a zone of tool punctations.

Four of the nine incised-punctated sherds are rims of Maydelle Incised vessels; 67\% of these sherds employ tool punctations as part of the decorative element. Two of these have incised triangles encircling the rim, and the triangles are either filled with tool punctations (see Figure 1e) or circular punctations (see Figure $1 \mathrm{~b}$ ); a body sherd also has a triangular incised zone filled with tool punctations. A third rim has diagonal incised panels filled with tool punctates (see Figure 1c), and the fourth has large and small curvilinear incised zones filled with tool punctates (see Figure 1d).

The 28 punctated sherds $(23 \%$ of the utility wares), among them two rims, include $10(36 \%)$ with rows of fingernail punctates and $18(64 \%)$ with tool punctated rows; the proportion of tool versus fingernail punctation as part of the decorative element is almost exactly the same as seen in the incised-punctated utility wares. There is a single Killough Pinched body sherd in the 41 HE 337 assemblage.

Two body sherds ( $1.6 \%$ ) have straight appliqued ridges on them. These ridges are probably oriented vertically on the body of cooking jars, whcre their purpose was to divide the body into panels.

\section{Fine Wares}

There are three kinds of fine wares at 41HE337: sherds from engraved vessels; sherds from redslipped bottles and bowls $(n=2,7.1 \%)$; and lip notched carinated bowl rims $(n=1,3.6 \%)$ (sce Table 1). The engraved sherds account for $89 \%$ of the fine wares. The vast majority of the engraved wares from the site are from Poynor Engraved (see Suhm and Jelks 1962) carinated bowls, with decorative motifs encircling the rim panel.

One of the rims from a carinated bowl has a series of horizontal engraved lines, a second has both horizontal and opposed lines (Figure 2b), while another has a hatched triangular zone along one side of an oval-shaped area (Figure $2 \mathrm{~h}$ ). Two others only have diagonal engraved lines on the rim. One rim peaked vessel has both a hatched triangular element (i.e., the quintessential Poynor Engraved decorative element) adjacent to an oval or semi-circular area that is bisected by a series of diagonal engraved lines (Figure $2 \mathrm{~g}$ ). The most unique engraved rim, resembling var. $S$ in the upper Neches River basin Poynor Engraved series (Perttula 2008), has a single horizontal engraved line just below the lip as well as diagonal lines reaching from near the lip to the carination; one of these engraved lines has a set of pendant semi-circles (Figure 2a). Var. S of Poynor Engraved is found in low frequencies in ca. A.D. 1400-1480 Frankston phase sites in the upper Neches (Perttula 2008: Table 6-37).

The body sherds with engraved elements include a number with simple geometric elements: horizontal lines $(n=1)$, diagonal lines $(n=1)$, parallel lines $(n=4)$, and single straight line $(n=3)$. There are also hatched ladder elements ( $n=1$, see Figure $2 f)$, ovals $(n=1)$, hatched triangles and eircles $(n=1$, see Figure 2e), and nested triangles (see Figure 2c). This particular sherd resembles var. E of Poynor Engraved, a post-A.D. 1480 variety in the upper Neches River basin (Perttula 2008:Table 6-37).

Two other sherds have only hatched triangles. One other, from a carinated bowl, has hatched triangles at the end of a scroll element (see Figure 2d). The last remaining carinated bowl engraved sherd from 41 HE337 has horizontal engraved lines and a circle element.

There is only a single bottle sherd in the engraved fine ware sherd sample from $41 \mathrm{HE} 337$. This has an excised triangle element pendant from a straight line.

Red-slipped sherds in the $41 \mathrm{HE} 337$ ceramic assemblage are from two different vessels. The first is a red-slipped (on both interior and exterior vessel surfaces) bowl or carinated bowl, and the second is from a bottle with an exterior red slip. In general, red-slipped vessels are rarely seen in post-A.D. 1300 upper Neches River basin Caddo sites.

The one lip notched rim (inverted rim with a beveled lip) has a regular series of notches cut into the lip. Examination of a large series of whole vessels from the upper Neches River basin suggests that lip notching (usually accompanying an engraved design on the rim panel) was a minor decorative element principally in post-A.D. 1480 Frankston phase contexts (Perttula 2008), but it has also been found in earlier habitation contexts in the basin, including among the ceramic sherds in the northern area (ca. A.D. 1320-1400) at the Lang Pasture site (41AN38)

\section{Use of Bone Temper in the Manufacture of Ceramic Vessels}

One of the technological features of the post-A.D. 1300 upper Neches River basin Caddo 


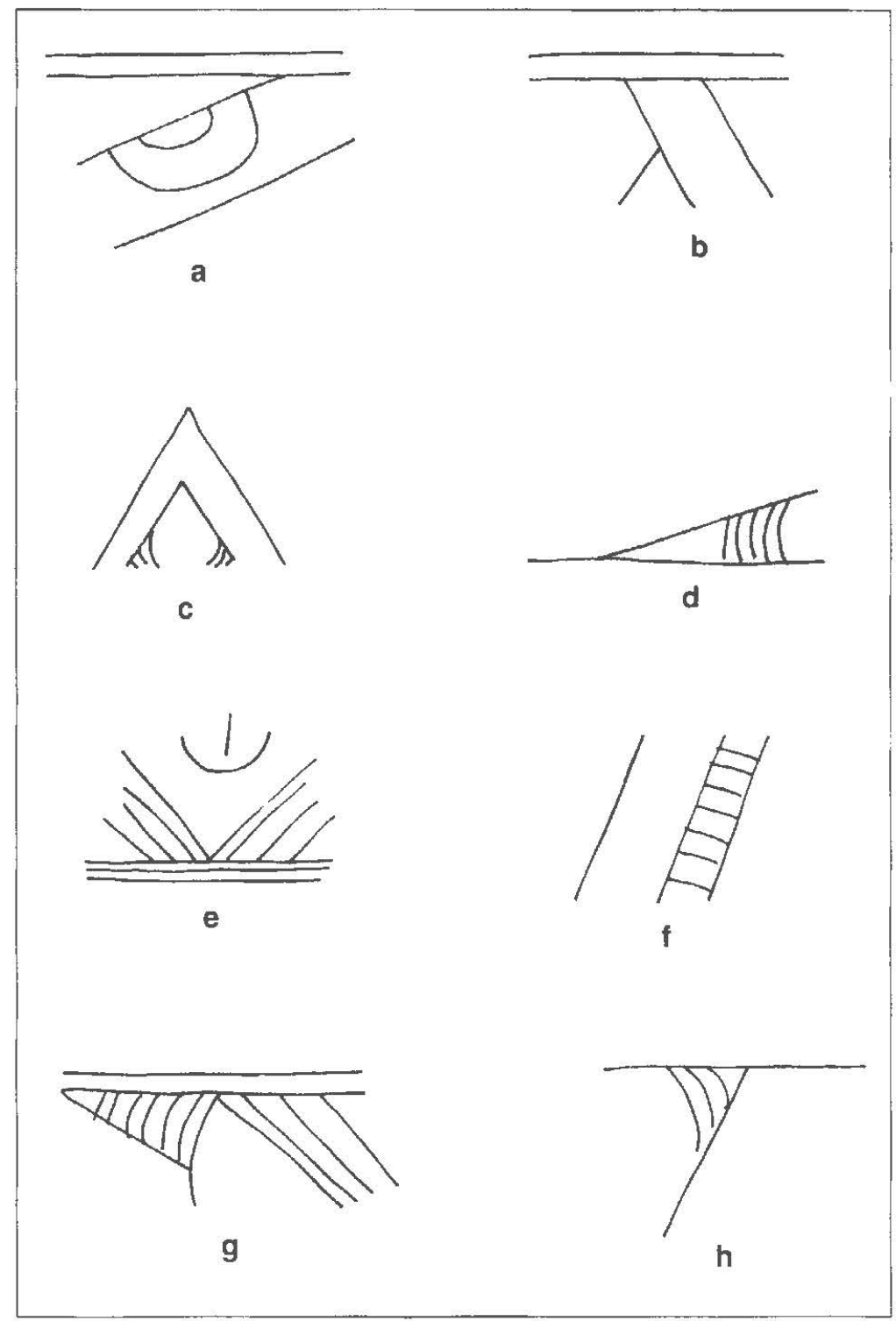

Figure 2. Engraved fine ware sherds from 41HE337: a, horizontal and diagonal semi-circle (Poynor Engraved); b, horizontal and opposed engraved lines; c, nested triangle (Poynor Engraved); d, hatched scroll element (Poynor Engraved); e, hatched triangles and circle (Poynor Engraved); f, hatched ladder; g, hatched triangle and diagonal engraved lines (Poynor Engraved): h, hatched triangle (Poynor Engraved).

ceramic tradition is the reliance by Caddo potters on the use of grog as the principal tempering aplastic (Perttula 2008). Such is the situation in the ceramic assemblage at $41 \mathrm{HE} 337$, where only $5.6 \%$ of the ceramic vessel sherds have bone temper inclusions (Table 2). Only the plain wares (i.e., bowis used in food serving) and decorated utility wares (i.e., used in cooking and storage tasks) at the site have bonetempered vessels.

\section{CONCLUSIONS}

The range of decorative elements and motifs in the utility ware and fine ware vessel sherds from $41 \mathrm{HE} 337$, as well as the infrequent use of bonetempering in vessel manufacture, indicate that the prehistoric ceramic vessel sherds here are trom, $15^{\text {th }}$ century Frankston phase occupation. The character of this assemblage is consistent with other documented Caddo sites in the upper Neches River 
Table 2. Use of bone temper in the different ceramic wares at $41 \mathrm{HE} 337$.

\begin{tabular}{lcc}
\hline Ware & $\begin{array}{c}\text { No. of } \\
\text { sherds }\end{array}$ & $\begin{array}{c}\text { Percent of } \\
\text { sherds with } \\
\text { bone temper }\end{array}$ \\
\hline Plain ware & 336 & 5.9 \\
Utility ware & 121 & 5.8 \\
Fine ware & 28 & 0.0 \\
\hline Total & 485 & 5.6 \\
\hline
\end{tabular}

basin that are part of a distinctive post-A.D. 1300 ceramic tradition.

In particular, the ceramic vessel assemblage from 41 HE337 includes a number of plain ware vessel sherds, as well as decorated utility wares and fine wares. The utility wares are dominated by incised and incised-punctated Maydelle Incised jars, some of which had been brushed on the vessel body, as well as tool or fingernail punctated jars. There is one Killough Pinched body sherd. The fine waresincluding one engraved bottle sherd, two red-slipped sherds, and a well-executed lip notched rim-are dominated by Poynor Engraved carinated bowl sherds, as is the case at all upper Neches River basin Frankston phase sites. These vessels have panels of engraved ovals, semi-circles, and nested triangles, as well as distinctive hatched triangle elements.

\section{END NOTE}

1. No arrow points or chipped stone tools were found at the site by Bill Young (May 2008 personal communication). There were a few small flakes, the base of a Dalton point, and a Gary point made of Uvalde gravels quartzite. There were also a very few tiny pieces of nondiagnostic bone.

\section{REFERENCES CITED}

Perttula. T. K.

2008 The Ceramic Artifacts from the Lang Pasture Site (41 AN38) and the Place of the Site within an Upper Neches River Basin Caddo Ceramic Tradition. MS on file with the author.

Suhm, D. A. and E. B. Jelks (editors)

1962 Handbook of Texas Archeology: Type Descriptions. Special Publication No. 1, Texas Archeological Society, and Bulletin No, 4, Texas Memorial Museum, Austin. 